\title{
Properties Evaluation by Thickness and Type of Oriented Strand Boards Manufactured in Continuous Press Line
}

\author{
Octavia Zeleniuc, ${ }^{\mathrm{a}}$ Adela-Eliza Dumitrascu, ${ }^{\mathrm{b}, *}$ and Valentina Doina Ciobanu ${ }^{\mathrm{c}}$ \\ Oriented strand boards (OSB) are widely used in construction to replace \\ plywood. There are four types of boards (OSB/1, OSB/2, OSB/3, and \\ $\mathrm{OSB} / 4$ ) that are used, depending on the conditions for use. This study \\ aimed to evaluate the physical and mechanical performance of these \\ types of boards having the following thicknesses: $10 \mathrm{~mm}, 11 \mathrm{~mm}, 18 \mathrm{~mm}$, \\ and $22 \mathrm{~mm}$. The boards were industrially manufactured using a continuous \\ press line. The results showed that the compression ratio increased with \\ decreasing of the wood strands' densities, from $1.3(\mathrm{OSB} / 1)$ to 1.1 \\ $(\mathrm{OSB} / 3)$. The thickness swelling values were lower for OSB/3 and OSB/2 \\ with $35 \%$ and $14 \%$, respectively, when compared to OSB/1. For these \\ boards, a slight increase in adhesive content and a lower speed of \\ pressing line was set, considering that they were designated for exterior \\ use. An increase in density with $7.6 \%$ led to an increase of approximately \\ $19 \%$ of the modulus of rupture (MOR), when comparing OSB $10 \mathrm{~mm}$ with \\ OSB $22 \mathrm{~mm}$. Improvements of $27 \%$ to $22 \%$ MOR and $13 \%$ to $10 \%$ \\ modulus of elasticity (MOE) for OSB/3 and OSB/2 compared to OSB/1 \\ were found. The internal bond (IB) values were approximately $32 \%$ higher \\ for OSB/3 than those reached by OSB $/ 1$, and the thinner boards registered \\ $25 \%$ higher IB values even after the boiling test, compared to the thicker \\ ones.
}

Keywords: Oriented strand board; Continuous press; Thickness; Board type; Press factor; Speed line; Physical properties; Mechanical properties

Contact information: a: Department of Wood Processing and Wood Products Design, Transilvania University of Brasov, 29 Eroilor Street, Brasov, Romania; b: Department of Manufacturing Engineering, Transilvania University of Brasov, 5 M. Viteazul Street, 500174, Brasov, Romania; c: Department of Forest Engineering, Forest Management Planning and Terrestrial Measurements, Transilvania University of Brasov, 1 Sirul Beethoven Street, Brasov, Romania; *Corresponding author: dumitrascu_a@unitbv.ro

\section{INTRODUCTION}

Oriented strand boards (OSB) are widely used as structural materials and have gained popularity in the market of construction raw materials, slowly replacing plywood. They are more flexible, cheaper, and have good performance in service. This type of panel has a large area of applications in construction for flooring, roofing, sidings, and for furniture, packing cases, and industrial containers. The world capacity for OSB rose from less than 2 million $\mathrm{m}^{3}$ (1996) to approximately 44 million $\mathrm{m}^{3}$ in 2017 (Wood Based Panels International 2019). Production of OSB continues to increase, reaching record production in Europe with approximately 8.4 million $\mathrm{m}^{3}$ in 2016 (Food and Agriculture Organization of the United Nations 2018). New capacities in Eastern Europe were developed. Poland expanded its capacity from 0.4 million $\mathrm{m}^{3}$ in 2014 to 0.74 million $\mathrm{m}^{3}$ in 2015 , joining Germany and Romania to form the "big three" in OSB (Wood Based Panels International 
2017). The evolution of global OSB production in relation with Europe and Romania is presented in Fig. 1.

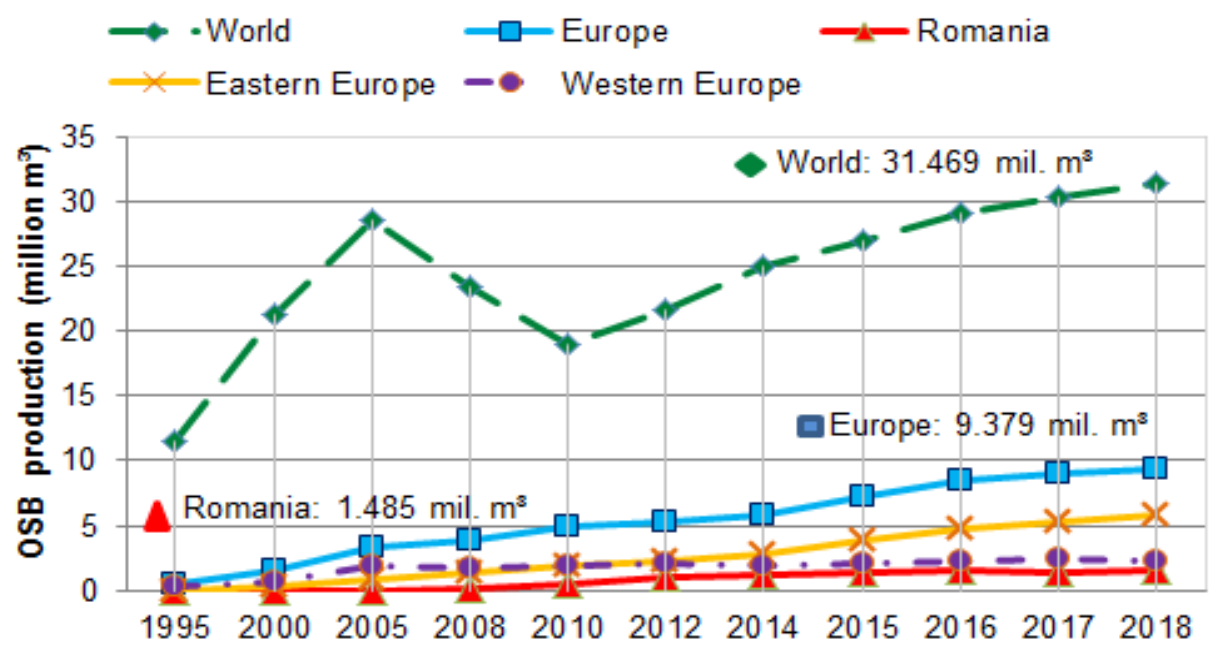

Fig. 1. OSB production in the world, Europe, and Romania between 1995 and 2018

As shown in Fig. 1, at a global level, the decline in housing in the US corresponded with a decrease in OSB production at a global level between 2005 and 2010. A rapid increase of production was mainly being determined by the new mills developed in Eastern Europe, including the Russian Federation, as well as increased production in China and Northern America. Europe recorded a growth rate of 29\% in 2018 compared to 2015, with Romania, Germany, and Poland as the main producers, which contributed approximately $45 \%$ of total production (Food and Agriculture Organization of the United Nations 2018).

According to EN 300 (2006), four quality types of OSB are manufactured. OSB/3 represents the majority of European OSB production, accounting for approximately $85 \%$, followed by OSB/2 with 10\%, and OSB/4 with 5\% (Mantanis et al. 2017). The properties of these OSB types are different and should meet the standard requirements. There are many parameters that affect the panel properties, such as raw material species, strands dimensions and quality, panel structure, resin type and receipt, pressure schedule, etc. The OSB properties are directly related to the natural strength properties of the wood raw material used, which is not homogeneous.

Studies have been conducted on OSB board manufactured at the laboratory level in specific conditions, where the effect of one parameter variation on the properties is analyzed. These included the evaluation of OSB properties related to density (Chen et al. 2010), mat structure (Mirski et al. 2016), wood species (Beck et al. 2010; Yong et al. 2012; Bufalino et al. 2015; Febrianto et al. 2015; Cetera et al. 2018), receipt and adhesive type (Yorur et al. 2013; Mantanis et al. 2017), treated strands (Papadopoulos and Traboulay 2002; Ferro et al. 2016), and insertion inside panels (Mendes et al. 2015). The experimental OSB panels were manufactured on a single opening press where the parameters are constant throughout the process (Lee and Md. Tahir 2003; Han et al. 2006; Sumardi et al. 2007; Hiziroglu 2009; Moya et al. 2009; Gündüz et al. 2011; Salari et al. 2012; Silva et al. 2012; Esen et al. 2013; Hidayat et al. 2013; Wong et al. 2013; Febrianto et al. 2015; Mirski and Dziurka 2015; Edalat et al. 2016). The pressing time ranged from $3 \mathrm{~min}$ to $12 \mathrm{~min}$, temperatures between $180{ }^{\circ} \mathrm{C}$ and $200{ }^{\circ} \mathrm{C}$, and pressure between 2.5 to $3.5 \mathrm{~N} / \mathrm{mm}^{2}$. The boards manually carried out included different percentage of adhesive, which in most cases 
is much higher than the ratio used in the production lines. Thus at laboratory scale diphenylmethane diisocyanate (MDI) values ranged from $7 \%$ to $10 \%$ (Febrianto et al. 2010; Hidayat et al. 2013; Dumitrascu et al. 2020), whereas the urea-formaldehyde (UF) and phenol-formaldehyde (PF) values were between 6\% and 15\% (Lee and Md. Tahir 2003; Hiziroglu 2009; Barbuta et al. 2012; Esen et al. 2013; Akyildiz et al. 2018). Accordingly, the resulted values of properties are usually higher than those obtained in production. The evaluation of properties are made on a single OSB board thickness, usually $12 \mathrm{~mm}$ (Lee and Md. Tahir 2003; Plenzler et al. 2013; Edalat et al. 2016) and $15 \mathrm{~mm}$ (Mirski and Dziurka 2015; Mirski et al. 2016; Cetera et al. 2018). The large variation in conditions is reflected in the different properties and performance of the obtained panels.

There have been several studies that analyzed the behavior of OSB boards produced in industrial conditions. These have referred to the differences between the face and core strength properties of OSB/3 with $18 \mathrm{~mm}$ thickness and made of pine (Plenzler et al. 2017), the contribution of face and core thickness swell to the total thickness swell of commercial OSB of $11 \mathrm{~mm}$ and $18 \mathrm{~mm}$ thicknesses made from a pine and hardwood mixture (Wang et al. 2003), the bending strength differences between the upper and lower faces of OSB/3 (Böhm et al. 2011), the impact of humid conditions through aging tests of $15 \mathrm{~mm} \mathrm{OSB} / 3$ and OSB/4 (Derkowski et al. 2014), and the swelling effect on internal bond of $15 \mathrm{~mm}$ OSB/3 and OSB/4 (Mirski et al. 2012). In the production process, panel performance relies directly on layer forming and pressing conditions and should fulfill standard requirements to maintain OSB's position on the market. Few publications have dealt with the analysis of OSB properties in real condition of pressing with continuous press (Hrázský and Král 2011; Ciobanu et al. 2014; Mirski 2016).

The most effective means to improve the quality of products and their performance in situ is to evaluate the physical and mechanical properties of boards carried out in industrial conditions. The aim of this research is to analyze the properties of OSB boards manufactured in industrial conditions, on continuous press line, and their variation in relation with the board thickness and OSB type based on the raw material and adhesive used. Many factors interfere and change during the manufacturing process thus, the influence of dynamic control of pressing parameters to the variation of properties is considered.

\section{EXPERIMENTAL}

\section{Materials}

Three types of OSB panels with different thicknesses were manufactured under industrial conditions on a forming line with a $53 \mathrm{~m}$ Dieffenbacher continuous press (Dieffenbacher GmbH Maschinen-und Anlagenbau, Eppingen, Germany), which operated at a speed of up to $1200 \mathrm{~mm} / \mathrm{s}$. The raw material wood species used included both resinous and hardwoods as shown in Table 1. All wood raw materials were supplied through the National Forest Administration from Romanian forests. The average moisture content of the raw materials ranged between $42 \%$ and $65 \%$, depending on the raw material assortments. A Leonhardt type strand flaker (Leonhardt GmbH, Losheim, Germany) was used, with a heavy-duty rotor and static knife ring that cut uniform flat strands. The wood strands dimensions were typically $120 \mathrm{~mm}$ along the grain and ranged from $5 \mathrm{~mm}$ to 50 $\mathrm{mm}$ across the grain. The strands thickness ranged between $0.4 \mathrm{~mm}$ to $0.6 \mathrm{~mm}$. 
Table 1. Raw Material Used for OSB Manufacturing

\begin{tabular}{|c|l|}
\hline OSB Type & \multicolumn{1}{c|}{ Raw Material } \\
\hline OSB/1 & $\begin{array}{l}\text { Exclusively made from strands of different coniferous species: spruce (Picea } \\
\text { abies), fir (Abies alba), pine (Pinus sylvestris), larch (Larix decidua) }\end{array}$ \\
\hline OSB/2 & Mixture of strands from coniferous species (75\%) and softwood species (25\%) \\
\hline OSB/3 & $\begin{array}{l}\text { Mixture of strands including 50\% coniferous species: spruce (Picea abies), fir } \\
\text { (Abies alba), pine (Pinus sylvestris), and larch (Larix decidua); 25\% hardwood } \\
\text { species: beech (Fagus sylvatica); and 25\% softwood species: aspen (Populus } \\
\text { tremula), birch (Pedula pendula), willow (Salix alba), and alder (Alnus glutinosa) }\end{array}$ \\
\hline
\end{tabular}

The strands were dried to 3\% moisture content (MC), sieved, and then blended with moisture resistant adhesives. Melamine-urea-formaldehyde (MUF) adhesive was used for faces (F) and polymeric diphenylmethane diisocyanate (pMDI) for core (C) (Kronospan, Brasov, Romania); wax and water were also added according to the recipes that were controlled and managed by a computer system. The adhesive percentages ranged between 2.4 to $3.4 \%$ for the face layers and between 2.1 to $3.1 \%$ for the core, based on the ovendried weight of the wood strands. The shell ratio (the ratio on a weight basis of faces to core materials) was kept for all the three-layer boards, into a range of 64 to 55:36 to 45 .

Forming and pressing was performed in industrial conditions with the Dieffenbacher continuous press. The pressing area was based on six groups of pressing, characterized by different temperatures and pressures. High temperature and pressure were established for the first 20 pressing frames ( 230 to $250^{\circ} \mathrm{C}$ and 4 to $5 \mathrm{~N} / \mathrm{mm}^{2}$, respectively), then these parameters decreased to a temperature of 190 to $220^{\circ} \mathrm{C}$ and a specific pressure of $1.5 \mathrm{~N} / \mathrm{mm}^{2}$ for the last 10 frames. After pressing, the boards were cut to size, cooled, and transported to the storage area. The target density of the boards varied between 550 $\mathrm{kg} / \mathrm{m}^{3}$ and $605 \mathrm{~kg} / \mathrm{m}^{3}$.

From the conditioned industrial boards, 30 boards dimensioned at $2500 \mathrm{~mm} \times 1250$ $\mathrm{mm}$ were chosen for analysis. The codification of the boards, the adhesive content for the faces $(\mathrm{F})$ and core $(\mathrm{C})$, and the pressing parameters are shown in Table 2.

Table 2. Characteristics of Industrial Manufacturing Process of OSB

\begin{tabular}{|c|c|c|c|c|c|c|}
\hline \multirow{2}{*}{ Board Code } & \multicolumn{2}{|c|}{$\begin{array}{c}\text { Adhesive Ratio } \\
(\%)\end{array}$} & \multirow{2}{*}{$\begin{array}{l}\text { Target } \\
\text { Density } \\
\left(\mathrm{kg} / \mathrm{m}^{3}\right)\end{array}$} & \multirow{2}{*}{$\begin{array}{c}\text { Board } \\
\text { Thickness } \\
\quad(\mathrm{mm})\end{array}$} & \multicolumn{2}{|c|}{ Pressing Parameters } \\
\hline & $\begin{array}{l}\text { MUF } \\
(\mathrm{F})\end{array}$ & $\begin{array}{l}\mathrm{pMDI} \\
(\mathrm{C})\end{array}$ & & & $\begin{array}{c}\text { Speed Line } \\
(\mathrm{mm} / \mathrm{s})\end{array}$ & $\begin{array}{c}\text { Press Factor } \\
(\mathrm{s} / \mathrm{mm})\end{array}$ \\
\hline OSB/1-10 & 2.4 & 2.1 & 600 & 10 & 800 & 7.05 \\
\hline OSB/1-11 & 3.0 & 2.7 & 590 & 11 & 1040 & 4.90 \\
\hline OSB/1-18 & 3.1 & 2.7 & 570 & 18 & 730 & 4.15 \\
\hline OSB/1-22 & 2.5 & 2.2 & 550 & 22 & 510 & 4.86 \\
\hline OSB/2-10 & 3.1 & 2.8 & 590 & 10 & 835 & 6.60 \\
\hline OSB/2-11 & 2.9 & 3.1 & 600 & 11 & 1000 & 5.05 \\
\hline OSB/2-18 & 3.0 & 3.1 & 580 & 18 & 690 & 5.11 \\
\hline OSB/2-22 & 2.5 & 2.2 & 570 & 22 & 500 & 5.20 \\
\hline OSB/3-10 & 3.4 & 2.8 & 600 & 10 & 860 & 6.40 \\
\hline OSB/3-11 & 3.3 & 2.9 & 605 & 11 & 975 & 5.18 \\
\hline OSB/3-18 & 2.6 & 2.2 & 590 & 18 & 609 & 5.00 \\
\hline OSB/3-22 & 3.0 & 2.2 & 550 & 22 & 440 & 5.60 \\
\hline
\end{tabular}




\section{Research Methodology}

Sampling was taken from each experimental board in accordance to the EN 326-1 (1994) standard. The physical and mechanical properties were determined as follows: density (D) according to EN 323 (1993), moisture content (MC) according to EN 322 (1993), thickness swelling (TS), water absorption (WA) after $24 \mathrm{~h}$ of soaking in water according to EN 317 (1993), modulus of rupture and modulus of elasticity (MOR/MOE) according to EN 310 (1993), internal bond strength (IB) according to EN 319 (1993), and internal bond after the boiling test (IB-BT) according to EN 1087-1 (1995). The samples were conditioned at $20 \pm 2{ }^{\circ} \mathrm{C}$ temperature and $65 \pm 5 \%$ relative humidity until they reached equilibrium moisture content. The mechanical properties were tested on a Zwick/RoellZ010 universal-testing machine (Zwick/Roell, Kennesaw, GA, USA) that was equipped with a $\pm 10 \mathrm{kN}$ load cell. One-way analysis of variance (ANOVA, using Microsoft Excel) was performed to evaluate the statistical effects of OSB board thickness and type on the properties of the panels. A statistical significance level of $\alpha \leq 0.05$ was selected.

\section{RESULTS AND DISCUSSION}

\section{Physical Properties Variation on Thickness and OSB Type}

The average values of the physical properties are shown in Table 3. The average moisture content (MC) values ranged from $4.17 \%$ to $6.19 \%$. The lowest values were recorded for $\mathrm{OSB} / 3$ and the highest for $\mathrm{OSB} / 1$. No noticeable differences were observed between $10 \mathrm{~mm}$ and $11 \mathrm{~mm}$ thicknesses, but slightly higher values were registered for 18 $\mathrm{mm}$ and $22 \mathrm{~mm}$ thicknesses.

Table 3. Physical Properties on Types and Thickness of OSB

\begin{tabular}{|c|c|c|c|}
\hline \multirow{2}{*}{$\begin{array}{c}\text { Board } \\
\text { Code/type- } \\
\text { thickness }\end{array}$} & \multicolumn{3}{|c|}{ Physical Properties (Average Values) } \\
\hline & $\begin{array}{c}\text { Moisture Content }(\mathrm{SD} \text { *) } \\
(\%)\end{array}$ & $\begin{array}{c}\text { TS } 24 \mathrm{~h}\left(\mathrm{SD}^{*}\right) \\
(\%)\end{array}$ & $\begin{array}{c}\text { WA } 24 \mathrm{~h}\left(\mathrm{SD}{ }^{*}\right) \\
(\%)\end{array}$ \\
\hline OSB/1-10 & $5.19(0.29)$ & $28.91(5.72)$ & $93.69(6.25)$ \\
\hline OSB/1-11 & $4.99(0.49)$ & $22.06(2.92)$ & $89.20(10.16)$ \\
\hline OSB/1- 18 & $6.19(0.62)$ & $22.21(2.52)$ & $92.11(6.97)$ \\
\hline OSB/1-22 & $6.06(0.86)$ & $23.90(1.85)$ & $95.27(6.23)$ \\
\hline \multicolumn{4}{|c|}{ OSB/1: the limit value in accordance to the EN 300 (2006): TS $24 \mathrm{~h}: 25 \%$} \\
\hline OSB/2-10 & $4.27(0.30)$ & $20.53(1.85)$ & $70.55(5.47)$ \\
\hline OSB/2-11 & $4.79(0.42)$ & $20.45(2.50)$ & $93.45(5.20)$ \\
\hline OSB/2-18 & $5.19(0.42)$ & $20.15(2.46)$ & $95.45(4.60)$ \\
\hline OSB/2- 22 & $5.47(0.39)$ & $22.77(1.93)$ & $101.21(6.91)$ \\
\hline \multicolumn{4}{|c|}{ OSB/2: the limit value in accordance to the EN 300 (2006): TS $24 \mathrm{~h}: 20 \%$} \\
\hline OSB/3-10 & $4.17(0.33)$ & $15.54(1.12)$ & $75.58(8.32)$ \\
\hline OSB/3-11 & $4.41(0.48)$ & $15.35(2.03)$ & $74.96(9.07)$ \\
\hline OSB/3-18 & $4.89(0.79)$ & $15,86(1.24)$ & $93.67(5.250$ \\
\hline OSB/3-22 & $4.64(0.30)$ & $16,82(2.09)$ & $95.13(1.97)$ \\
\hline \multicolumn{4}{|c|}{ OSB/3: the limit value in accordance to the EN 300 (2006): TS $24 \mathrm{~h}: 15 \%$} \\
\hline
\end{tabular}

The interdependence between the wood raw material density, board density, and the pressing parameters is represented in Fig. 2. Overall, the average density was above the target density for all board types, except for the OSB $11 \mathrm{~mm}$ thickness. The lowest density, $566 \mathrm{~kg} / \mathrm{m}^{3}$, was obtained for OSB/3 at $22 \mathrm{~mm}$ thickness, which had a lower compaction 
ratio compared to $\mathrm{OSB} / 2$ and $\mathrm{OSB} / 1$. The pressing parameters varied in some limits depending on the board thickness and type. The lowest speed line was set for the boards with $22 \mathrm{~mm}$ thickness and the highest for those with $10 \mathrm{~mm}$ and $11 \mathrm{~mm}$ thickness. Increasing the speed line in the conditions of maintaining the press factor at almost the same value led to lower densities (below the target limit), as observed for OSB $11 \mathrm{~mm}$ (Fig. 2).

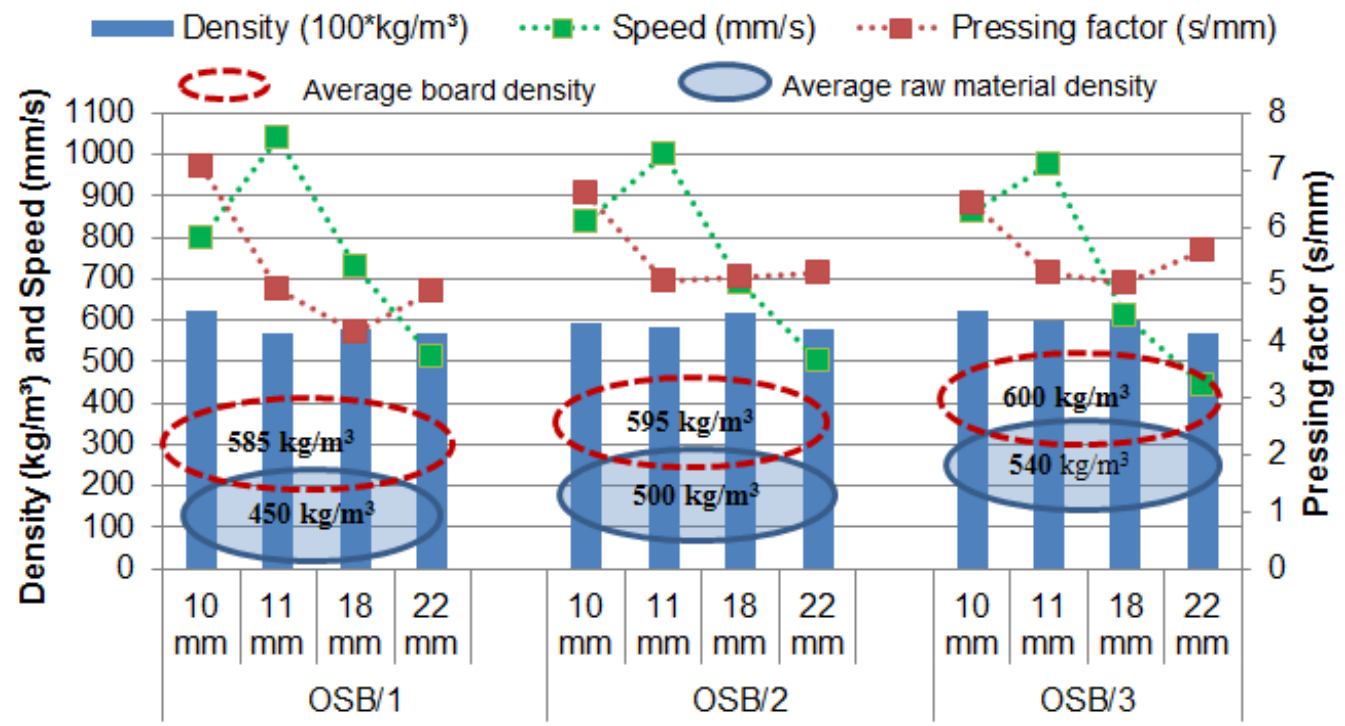

Fig. 2. Interrelation between the pressing parameters, density, board thickness, and OSB type

The average density of the boards increased with the wood raw material density by a factor (compression ratio) between 1.1 and 1.3, which was in agreement with some studies that specify the board should be compressed to a density 1.2 to 1.9 times than the initial strands density, to have satisfactory contact between strands (Bowyer et al. 2003; Bufalino et al. 2015).

\section{Thickness Swelling and Water Absorption}

Thickness swelling values (TS) ranged between $15.4 \%$ and $28.9 \%$ (Table 3). The specimens with the lowest adhesive content had the highest TS values $28.9 \%, 23.9 \%$, and $22.8 \%$ for OSB/1-10 mm, OSB/1-22 mm, and OSB/2-22 mm, respectively (Fig. 3). An increase in adhesive content (both for faces and core) determined a decrease in TS, which was more evident for OSB/3 with thicknesses of $10 \mathrm{~mm}$ and $11 \mathrm{~mm}$. This behavior agreed with literature (Liu and McNatt 1991; Wang et al. 2003; Zhang et al. 2007), which specified that a high resin content and high moisture content could decrease the thickness swelling. The specimens with the highest pMDI content (i.e., OSB of $11 \mathrm{~mm}$ thickness) and higher speed lines (over $1000 \mathrm{~mm} / \mathrm{s}$ ) registered a lower TS compared to the other specimens. Akrami (2014) also observed that pMDI in the core layer gave a good weathering resistance at high line speeds and a press factor between 4 to $8 \mathrm{~s} / \mathrm{mm}$. A slight exceeding of the standard recommendations EN 300 (2006) regarding TS was observed. This could be a result of less uniform density distribution of strands in the board thickness, degree of bonding (Lin et al. 2013), and furnish quality. Boards from lower wood density (i.e., OSB/1 manufactured from coniferous species) resulted in higher thickness swelling, compared to boards from higher wood density or mixed wood species (OSB/2 and OSB/3), 
which was consistent with results of Hidayat (2009) and Wu and Piao (1999). However, the results concerning the influence of density on TS were contradictory. Higher density boards absorb water more slowly, reducing the rate of TS, but in time, water penetrates the cell walls of the inner layers of boards, increasing TS (Semple et al. 2009; Chen et al. 2010). Generally, TS increased with the board thickness, and greater values were registered for boards with $22 \mathrm{~mm}$ thickness (Fig. 3).

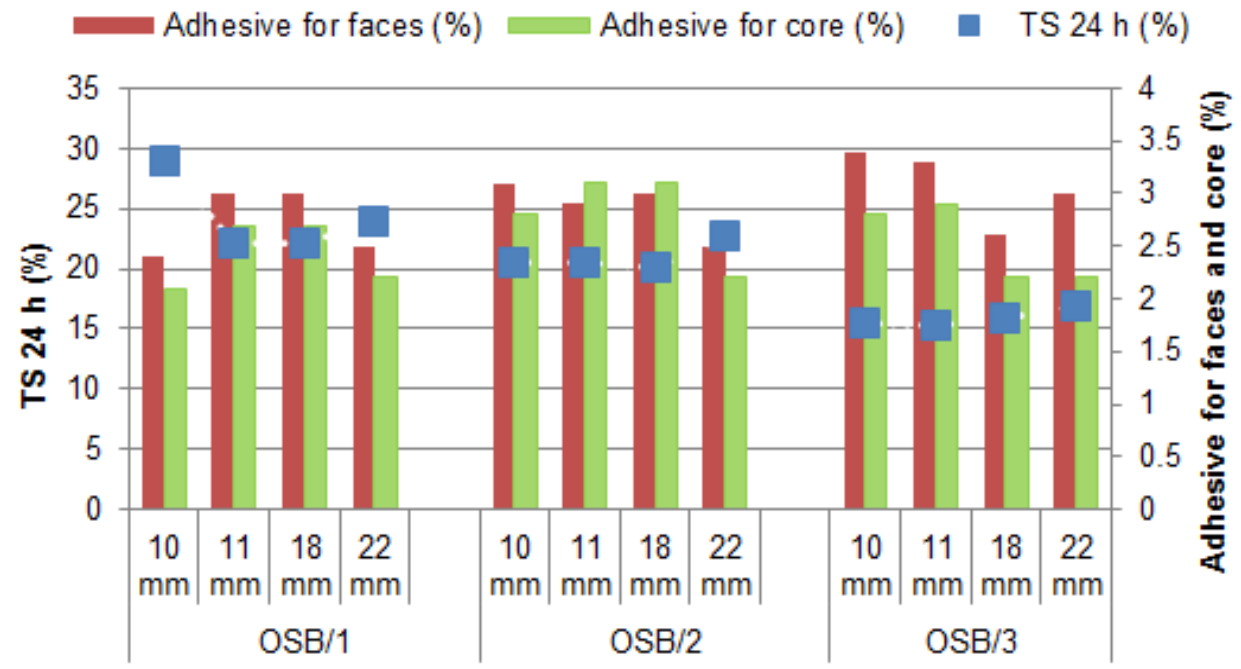

Fig. 3. The influence of adhesive content on thickness swelling for all boards

Water absorption (WA) ranged between $70.6 \%$ and $101.2 \%$. Generally, the highest values were observed for $22 \mathrm{~mm}$ thickness for all types of boards. Both WA and TS values were slightly greater for OSB/1 than for OSB/2 and OSB/3. The differences in the wood raw material used for strands influenced the resistance to water. Like TS, WA was also dependent on the wood raw material density and resin type. Low-density wood species with great porosity used for OSB/1 and in a high percentage for OSB/2, led to higher WA compared to OSB/3 manufactured mostly from high-density wood species. A low value of WA was observed for specimens (OSB $11 \mathrm{~mm}$ thickness) with higher pMDI contents. This adhesive can react with -OH groups of wood cellulose, increasing the resistance to water (Xiao et al. 2012).

\section{Mechanical Properties}

The average values for bending modulus (MOE) and strength (MOR) in the parallel direction, for each board thickness and OSB type, are plotted in Fig. 4. Generally, the mechanical properties increased from $\mathrm{OSB} / 1$ to $\mathrm{OSB} / 3$, the greater value being registered for OSB/3 (MOR- $26 \mathrm{~N} / \mathrm{mm}^{2}$ and MOE-4613 N/mm²). There was a slight variation of values between $\mathrm{OSB} / 2$ and $\mathrm{OSB} / 3$. The values of MOR and MOE for all boards were higher than the standard recommendations of EN 300 (2006) (Fig. 4).

The highest press factor (about $6.5 \mathrm{~s} / \mathrm{mm}$ ) was applied to $10 \mathrm{~mm}$ thickness for all types of boards; consequently, the highest density and MOR were obtained when compared to $22 \mathrm{~mm}$ thickness at $5.26 \mathrm{~s} / \mathrm{mm}$ (Figs. 2 and 4). An increase in density with approximately $7.6 \%$ led to an increase with approximately 19\% of MOR, when comparing OSB $10 \mathrm{~mm}$ with OSB $22 \mathrm{~mm}$. This agreed with literature that confirmed an increase of mechanical properties with increases in density (Gu et al. 2005; Jin et al. 2009; Chen et al. 2010). 
Within OSB types, the lowest press factor was applied for OSB/1 (except for $10 \mathrm{~mm}$ thickness), which does not require high durability and moisture resistance for its domain of use.

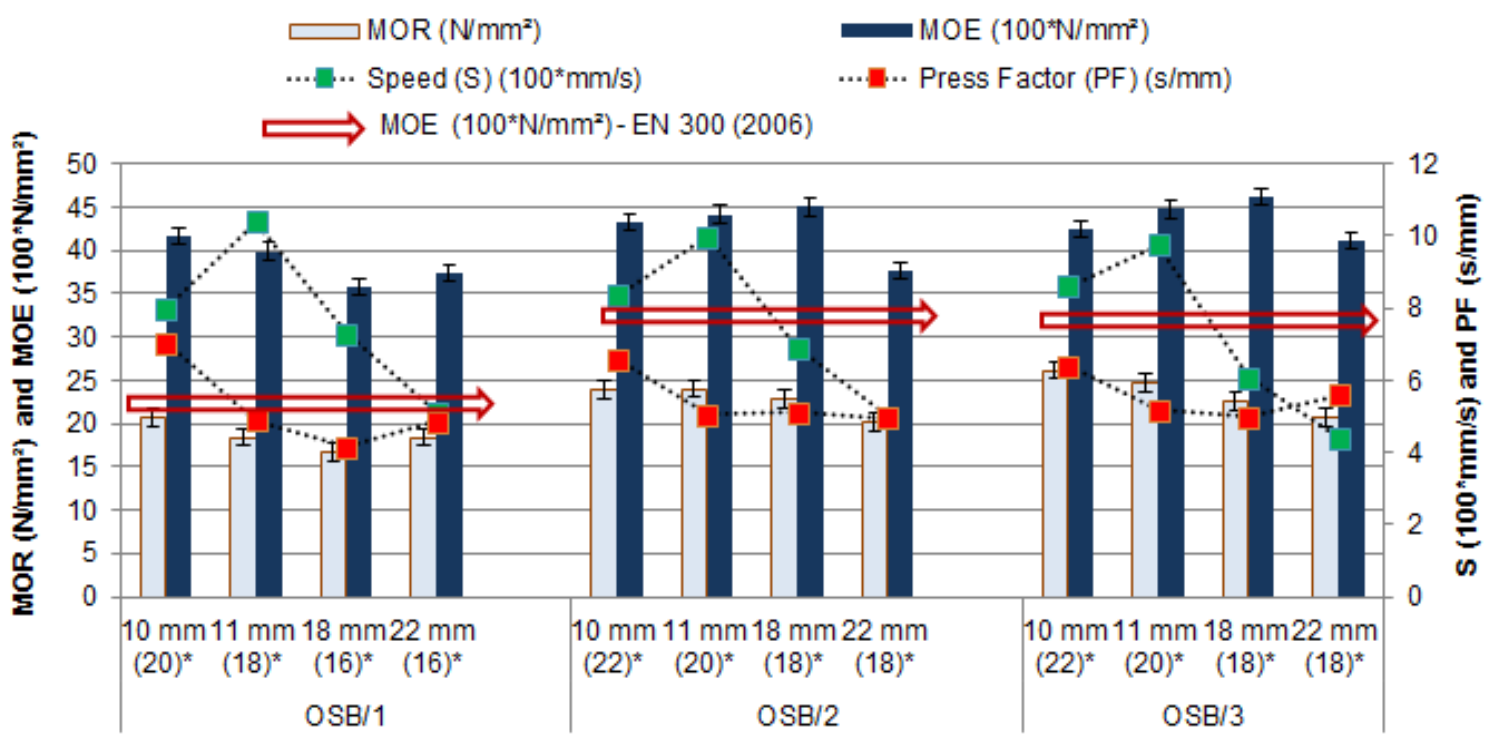

* Limit values for MOR (N/mm²) in accordance with EN 300 (2006) standard

Fig. 4. Mechanical properties (MOR, MOE) variation on the board thickness and OSB type

No remarkable differences in MOE between thicknesses, within each OSB type, were observed. The highest values were reached at $11 \mathrm{~mm}$ and $18 \mathrm{~mm}$ thicknesses for $\mathrm{OSB} / 2$ and OSB/3 (4400 N/mm ${ }^{2}$ and $4600 \mathrm{~N} / \mathrm{mm}^{2}$, respectively) and the lowest value at $22 \mathrm{~mm}$ thickness for all types of boards $\left(3740 \mathrm{~N} / \mathrm{mm}^{2}, 3764 \mathrm{~N} / \mathrm{mm}^{2}\right.$, and $4109 \mathrm{~N} / \mathrm{mm}^{2}$ for $\mathrm{OSB} / 1, \mathrm{OSB} / 2$, and OSB/3, respectively) (Fig. 4). For small thicknesses of boards, the speed of the line was approximately $45 \%$ higher than that of $22 \mathrm{~mm}$ for all types of boards. Within the board types, the slowest line speed $(440 \mathrm{~mm} / \mathrm{s})$ combined with high press factor $(5.6 \mathrm{~s} / \mathrm{mm})$ was achieved at OSB/3 of $22 \mathrm{~mm}$ to achieve the adequate transfer of heat into the core layer (Fig. 4). However, the press factor increased by 1.14 to 1.45 times from the OSB/3 type to the OSB/1 type, which led to $7 \%$ increase in density $7 \%$ and consequently an MOR of approximately $18 \%$ when comparing the $10 \mathrm{~mm}$ to $22 \mathrm{~mm}$ thickness.

\section{Internal Bond}

Internal bond strength (IB) is a measure of the inner bond quality between the strands of board. The average values of IB ranged from 0.26 to $0.46 \mathrm{~N} / \mathrm{mm}^{2}$ and between 0.06 and $0.16 \mathrm{~N} / \mathrm{mm}^{2}$ after the boiling test (Fig. 5). The highest values occurred in OSB/3 (with an average of $0.40 \mathrm{~N} / \mathrm{mm}^{2}$ ), with approximately $32 \%$ higher average values than those reached by OSB/1. A lower level of adhesive was applied at $22 \mathrm{~mm}$ board thickness (2.2\% for core and between $2.5 \%$ to $3 \%$ for faces), for all types of boards. For these boards, a lower value of IB was registered with approximately $20 \%$ and $24 \%$ (for boil test) when compared to $11 \mathrm{~mm}$ thickness. The lowest density (average $567 \mathrm{~kg} / \mathrm{m}^{3}$ ) and line speed (average $483 \mathrm{~s} / \mathrm{mm}$ ) were registered for the $22-\mathrm{mm}$ boards influenced the consolidation of mat and the inter-contact between strands, resulting in lower IB strength. However, the IB values were within the limits specified in EN 300 (2006) for all OSB types and thicknesses. 


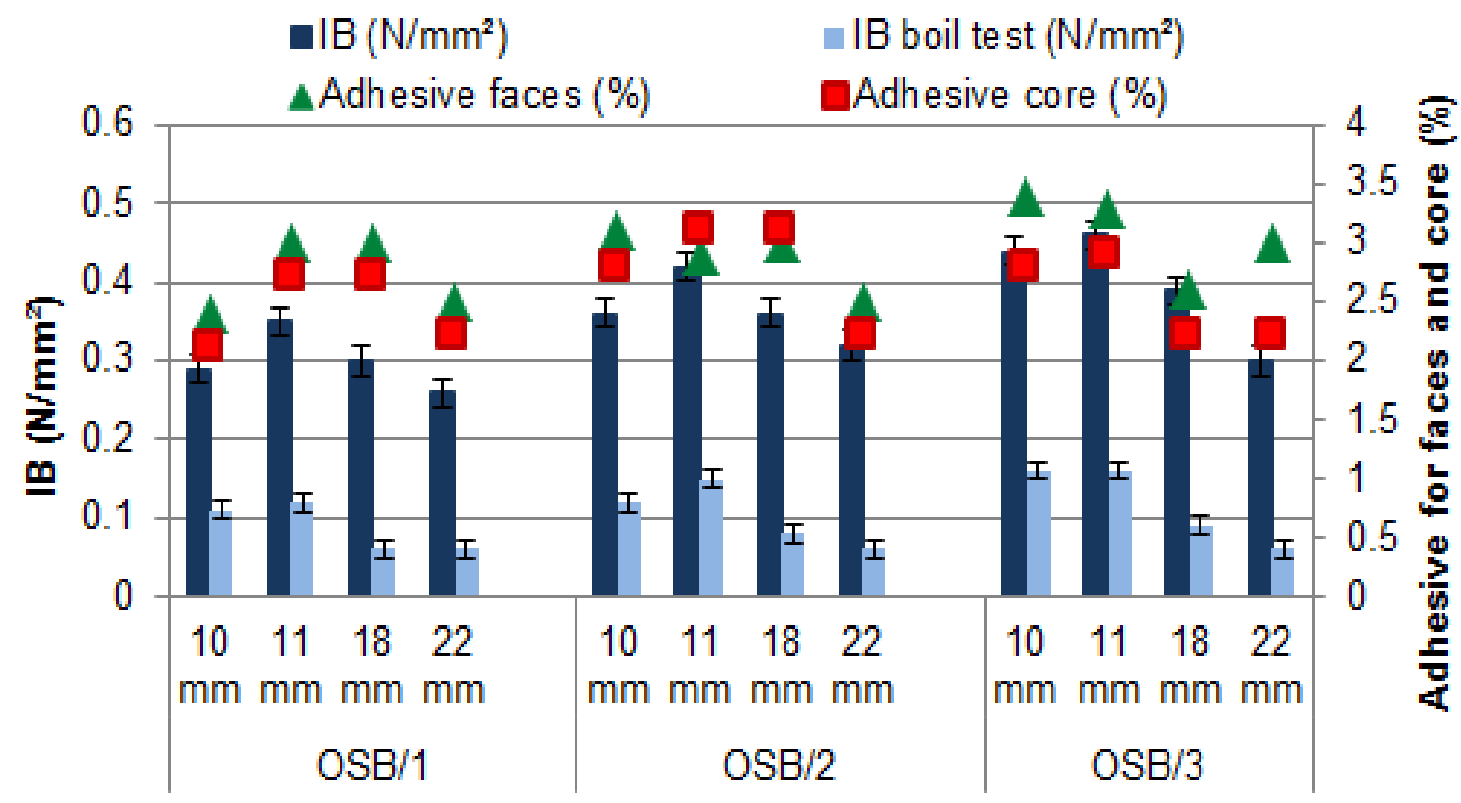

Fig. 5. Internal bond in correlation with the adhesive content

A boiling test is especially required for the boards exposed to exterior humid conditions corresponding to OSB/3. The performance of the boards after the boil test was different; the highest values were registered for the board with $10 \mathrm{~mm}$ and $11 \mathrm{~mm}$ thicknesses, for all OSB types, and their values varied from $0.16 \mathrm{~N} / \mathrm{mm}^{2}$ to $0.11 \mathrm{~N} / \mathrm{mm}^{2}$ (with lower values for OSB/1). Poor performances were obtained for $18 \mathrm{~mm}$ and $22 \mathrm{~mm}$ thicknesses for all of the board types, with IB reaching only $0.06 \mathrm{~N} / \mathrm{mm}^{2}$. The IB after the boiling test was affected by the lower board density and the small adhesive content of the thicker boards compared to the thinner ones. These results agreed with the literature (Beck et al. 2010; Mirski and Derkowski 2011). For all boards, the minimum value of $0.13 \mathrm{~N} / \mathrm{mm}^{2}$ recommended for OSB/3 after boiling test was reached only by OSB/3 with $10 \mathrm{~mm}$ and 11 $\mathrm{mm}$ thicknesses. The other boards failed, being below the requirement of $0.12 \mathrm{~N} / \mathrm{mm}^{2}$ mentioned in EN 300 (2006).

Table 4. Effect of OSB Thickness and Type on Physical and Mechanical Properties

\begin{tabular}{|c|c|c|}
\hline \multirow{2}{*}{$\begin{array}{l}\text { Physical and } \\
\text { mechanical properties }\end{array}$} & \multicolumn{2}{|c|}{ Statistical analysis. The influence of: } \\
\hline & A. Type of Board & B. Board thickness \\
\hline TS, WA & $\begin{array}{l}\text { Significant influence, for all the } \\
\text { board thicknesses } \\
\text { p-values less than } 0.001\end{array}$ & $\begin{array}{l}\text { Significant Influence only for } \\
\text { OSB } / 1 \\
p \text {-values of } 0.006\end{array}$ \\
\hline $\mathrm{IB}, \mathrm{MOR}$ & $\begin{array}{l}\text { Significant influence for } 10 \mathrm{~mm} \\
\text { and } 18 \mathrm{~mm} \text { board thicknesses } \\
\text { p-values less than } 0.008\end{array}$ & $\begin{array}{l}\text { Significant Influence only for } \\
\text { OSB/3 } \\
p \text {-values of } 0.001\end{array}$ \\
\hline MOE & $\begin{array}{l}\text { Significant influence only for } 18 \\
\text { mm board thickness } \\
\text { p-values of } 0.00002\end{array}$ & $\begin{array}{l}\text { Insignificant for all type of } \\
\text { boards } \\
\text { p-values greater than } 0.08\end{array}$ \\
\hline
\end{tabular}

Statistical analyses showed that the physical and mechanical properties of the experimental boards were differently influenced by the type of board and their thickness, as is shown in Table 4. 


\section{CONCLUSIONS}

1. The obtained results demonstrated that properties varied by board thickness and oriented strand board (OSB) type and were influenced by interrelation of three major factors: raw material species, adhesives, and pressing parameters. Wood species is one of the most important factors in the OSB manufacturing. It interacts virtually with every other variable from the process. Wood strands with lower density required a higher compression ratio to reach a similar target density with boards made from higher strands density

2. The water absorption (WA) and thickness spreading (TS) values were lower for OSB/3 than for OSB/2 and OSB/1. The boards manufactured from a lower wood density and greater porosity (i.e., OSB/1 manufactured from coniferous species) resulted in higher TS and WA, compared to boards from a higher wood density or mixed wood species $(\mathrm{OSB} / 3)$.

3. Increases in adhesive content (both for faces and core) determined a decrease in TS that was more evident for boards with $10 \mathrm{~mm}$ and $11 \mathrm{~mm}$ thicknesses when compared to boards with $22 \mathrm{~mm}$ thickness for all board types.

4. Mixing strands from high wood density with low wood density improved the strength properties. Greater values of modulus of rupture (MOR) and modulus of elasticity MOE were registered for OSB/3.

5. The dynamic control of the pressing factor and speed line influenced the properties by board thickness and OSB type. The highest press factor set for boards with $10 \mathrm{~mm}$ thickness led to an increased density and consequently better MOR values than those obtained for boards with $22 \mathrm{~mm}$ thickness.

6. No remarkable differences in MOE between the board thicknesses, within each OSB type, were observed. The highest values were reached at $18 \mathrm{~mm}$ for OSB/2 and OSB/3. A slight difference was achieved between OSB/2 and OSB/3 concerning MOR and MOE but a reduced swelling rate was acquired for OSB/3.

7. Internal bond strength reached the highest values on OSB/3. At a higher content of adhesive in the core and faces layers, an increase of IB was observed, especially at 10 $\mathrm{mm}$ and $11 \mathrm{~mm}$ board thicknesses. The lowest density and adhesive level influenced the inter-contact between strands, resulting in a lower IB strength for $22 \mathrm{~mm}$ thickness of all boards.

8. The internal bond (IB) after boiling test was affected by the lower board density and the small adhesive content of the thicker boards compared to the thinner ones. The highest values were registered for OSB/3 with $10 \mathrm{~mm}$ and $11 \mathrm{~mm}$ thicknesses, which demonstrated their resistance in external conditions.

9. A higher density of wood strands and a higher board density was obtained and consequently, higher mechanical properties (OSB/3 compared to OSB/1). OSB/3 made mostly of hardwood species was stiffer, had higher IB, and swelled less compared to $\mathrm{OSB} / 1$. 


\section{ACKNOWLEDGMENTS}

The authors are grateful to "Transilvania" University of Brasov for the support to perform this study.

\section{REFERENCES CITED}

Akrami, A. (2014). Development and Characterization of Oriented Strand Boards Made from the European Hardwood Species: Beech (Fagus sylvatica L.) and Poplar (Populus tremula L.), Ph.D. Dissertation, University of Hamburg, Hamburg, Germany.

Akyildiz, M. H., Dogan, K., and Kaymakci, A. (2018). "The impact of density and mixture ratio of melamine on some properties of oriented strand board," Maderas. Ciencia y Tecnología 20(3), 417-430. DOI: 10.4067/S0718-221X2018005031201

Barbuta, C., Blanchet, P., and Cloutier, A. (2012). "Mechanical properties of unidirectional oriented strand board with flat vertical density profile," Journal of Materials Science Research 1(3), 42-49. DOI: 10.5539/jmsr.v1n3p42

Beck, K., Cloutier, A., Salenikovich, A., and Beauregard, R. (2010). "Comparison of mechanical properties of oriented strand board made from trembling aspen and paper birch," European Journal of Wood and Wood Products 68(1), 27-33. DOI: 10.1007/s00107-009-0350-0

Böhm, M., Sedivka, P., Bomba, J., and Reisner, J. (2011). "Strength characteristics of OSB in bending - Difference between upper and lower panel faces," Drvna Industrija 62(2), 123-127. DOI: 10.5552/drind.2011.1036

Bowyer, J. L., Shmulsky, R., and Haygreen, J. G. (2003). Forest Products and Wood Science - An Introduction ( $4^{\text {th }}$ Ed.), Wiley-Blackwell, Hoboken, NJ, USA.

Bufalino, L., Corrêa, A. A. R., Aparecida de Sá, V., Mendes, L. M., Almeida, N. A., and Pizzol, V. D. (2015). "Alternative compositions of oriented strand boards (OSB) made with commercial woods produced in Brazil," Maderas. Ciencia y Tecnología 17(1), 105-116. DOI: 10.4067/S0718-221X2015005000011

Cetera, P., Negro, F., Cremonini, C., and Todaro, L. (2018). "Physico-mechanical properties of thermally treated poplar OSB," Forests 9, 345. DOI: 10.3390/f9060345

Chen, S., Du, C., and Wellwood, R. (2010). "Effect of panel density on major properties of oriented strandboard," Wood and Fiber Science 42(2), 177-184.

Ciobanu, V. D., Zeleniuc, O., Dumitrascu, A.-E., Lepadatescu, B., and Iancu, B. (2014). "The influence of speed and press factor on oriented strand board performance in continuous press," BioResources 9(4), 6805-6816. DOI: 10.15376/biores.9.4.68056816

Derkowski, A., Mirski, R., Dziurka, D., and Popyk, W. (2014). "Possibility of using accelerated aging tests to assess the performance of OSBs exposed to environmental conditions," BioResources 9(2), 3536-3549. DOI: 10.15376/biores.9.2.3536-3549

Dumitrascu, A.-E., Lunguleasa, A., Salca, E.-A., and Ciobanu, V. D. (2020). "Evaluation of selected properties of oriented strand boards made from fast growing wood species," BioResources 15(1), 199-210. DOI: 10.15376/biores.15.1.199-210

Edalat, H., Faezipour, M., and Thole, V. (2016). "How adhesive penetration effects on mechanical performances of OSB," in: World Conference on Timber Engineering WCTE 2016, Vienna, Austria. 
EN 1087-1 (1995). "Particleboards - Determination of moisture resistance - Part 1: Boil test," European Committee for Standardization, Brussels, Belgium.

EN 300 (2006). "Oriented strand boards (OSB). Definitions, classification and specifications," European Committee for Standardization, Brussels, Belgium.

EN 310 (1993). "Wood-based panels. Determination of modulus of elasticity in bending and of bending strength," European Committee for Standardization, Brussels, Belgium.

EN 317 (1993). "Particleboards and fibreboards. Determination of swelling in thickness after immersion in water," European Committee for Standardization, Brussels, Belgium.

EN 319 (1993). "Particleboards and fiberboards. Determination of tensile strength perpendicular to the plane of the board," European Committee for Standardization, Brussels, Belgium.

EN 322 (1993). "Wood-based panels. Determination of moisture content," European Committee for Standardization, Brussels, Belgium.

EN 323 (1993). "Wood-based panels. Determination of density," European Committee for Standardization, Brussels, Belgium.

EN 326-1 (1994). "Wood-based panels - Sampling, cutting, and inspection. Part 1: Sampling and cutting of test pieces and expression of test results," European Committee for Standardization, Brussels, Belgium.

Esen, R., Yapici, F., and Yorur, H. (2013). "The effects of press time and press pressure on the screw strength properties of oriented strand board (OSB) manufactured from scots pine," PRO LIGNO 9(4), 456-459.

Febrianto, F., Hidayat, W., Samosir, T. P., Lin, H. C., and Soong, H. D. (2010). "Effect of Strand combination on dimensional stability and mechanical properties of oriented strand board made from tropical fast growing tree species," Journal of Biological Sciences 10(3), 267-272.

Febrianto, F., Jang, J.-H., Lee, S.-H., Indra, A., Hidayat, S., Kwon, J.-H., and Kim, N.-H. (2015). "Effect of bamboo species and resin content on properties of oriented strand board prepared from steam-treated bamboo strands," BioResources 10(2), 2642-2655. DOI: 10.15376/biores.10.2.2642-2655

Ferro, F. S., Hendrigo de Almeida, T., Henrique de Almeida, D., Christoforo, A. L., and Lahr, F. A. R. (2016). "Physical properties of OSB panels manufactured with CCA and CCB treated Schizolobium amazonicum and bonded with castor oil based polyurethane resin," International Journal of Materials Engineering 6(5), 151-154. DOI: 10.5923/j.ijme.20160605.02

Food and Agriculture Organization of the United Nations (2018). "Forest product consumption and production," FAO, (http://www.fao.org/forestry/statistics/80938@180723/en/), Accessed 22 Aug 2019.

Gu, H., Wang, S., Neimsuwan, T., and Wang, S. (2005). "Comparison study of thickness swell performance of commercial oriented strandboard flooring products," Forest Products Journal 55(12), 239-245.

Gündüz, G., Yapici, F., Özçifçi, A., and Kalaycıŏglu, H. (2011). “The effects of adhesive ratio and pressure time on some properties of oriented strand board," BioResources 6(2), 2118-2124. DOI: 10.15376/biores.6.2.2118-2124

Han, G., Wu, Q., and Lu, J. Z. (2006). "Selected properties of wood strand and oriented strandboard from small-diameter southern pine trees," Wood and Fiber Science 38(4), 621-632. 
Hidayat, W. (2009). Preparation and Properties Enhancement of Oriented Strand Board Made from Tropical Fast Growing Tree Species, Master's Thesis, National Chiayi University, Chiayi, Taiwan.

Hidayat, W., Anne, C., and Febrianto, F. (2013). "Physical, mechanical, and durability properties of OSB prepared from CCB treated fast growing tree species strands," Journal of Tropical Wood Science and Technology 11(1), 55-61.

Hiziroglu, S. (2009). "Properties of strand board panels manufactured from Eastern redcedar," Materials 2(3), 926-933. DOI: 10.3390/ma2030926

Hrázský, J., and Král, P. (2011). "Optimisation of a pressing diagram in OSB pressing," Dravna Industrija 62(1), 27-35. DOI: 10.5552/drind.2011.1032.

Jin, J., Dai, C., Hsu, W. E., and Yu, C. (2009). "Properties of strand boards with uniform and conventional vertical density profiles," Wood Science and Technology 43(7-8), 559-574. DOI: 10.1007/s00226-009-0248-3

Lee, O. L., and Md. Tahir, P. (2003). Effects of fine particle content on the properties of five-layered oriented strand board, The XII World Forestry Congress, Quebec, Canada, (http://www.fao.org/3/XII/0692-A2.htm), Accessed 14 May 2020.

Lin, C.-H., Yang, T.-H., Lai, W.-J., and Lin, F.-C. (2013). "Anisotropic physical and mechanical performance of PF-impregnated oriented strand board," BioResources 8(2), 1933-1945. DOI: 10.15376/biores.8.2.1933-1945

Liu, J. Y., and McNatt, J. D. (1991). “Thickness swelling and density variation in aspen flakeboard," Wood Science and Technology 25, 73-82. DOI: 10.1007/BF00195558

Mantanis, G., Athanassiadou, E., Barbu, M. C., and Wijnendaele, K. (2017). "Adhesive systems used in the European particleboard, MDF and OSB industries," Wood Material Science and Engineering 13(2), 104-116. DOI: 10.1080/17480272.2017.1396622

Mendes, R. F., Da Silva César, A. A., Gomes da Silva, M., Mendes, L. M., and Carvalho, A. G. (2015). "Properties of OSB panels with veneer inclusion," Maderas. Ciencia y Tecnologia 17(4), 843-856. DOI: 10.4067/S0718-221X2015005000073

Mirski, R., and Derkowski, A. (2011). "Properties of OSB subjected to the boiling test," Acta Scientiarum Polonorum 10(2), 43-49.

Mirski, R., and Dziurka, D. (2015). "Low-density oriented strand boards Low-density oriented strand boards," BioResources 10(4), 6388-6394. DOI: 10.15376/biores.10.4.6388-6394

Mirski, R., Dziurka, D., and Derkowski, A. (2016). "Properties of oriented strand boards with external layers made of non-strand chips," BioResources 11(4), 8344-8354. DOI: 10.15376/biores.11.4.8344-8354

Mirski, R., Majka, J., and Dziurka, D. (2012). "The effect of residual swelling after drying on internal bond in OSB," Drvna Industrija 63(4), 241-247. DOI: 10.5552/drind.2012.1213

Moya, L., Tze, W. T. Y., and Winandy, J. E. (2009). "The effect of cyclic relative humidity changes on moisture content and thickness swelling behavior of oriented strandboard," Wood and Fiber Science 41(4), 447-460.

Papadopoulos, A. N., and Traboulay, E. (2002). "Dimensional stability of OSB made from acetylated Fir strands," Holz als Roh- und Werkstoff 60(2), 84-87. DOI: 10.1007/s00107-001-0248-y

Plenzler, R., Ludwiczak-Niewiadomska, L., and Mielcarek, P. (2013). "Shear and bending properties of structural oriented strand boards osb/4," Wood Research 58(2), 285-294. 
Plenzler, R., Ludwiczak-Niewiadomska, L., and Strzelecki, P. (2017). "Elastic and strength properties of OSB layers," Drvna Industrija 68(1), 3-9. DOI: 10.5552/drind.2017.1521

Salari, A., Tabarsa, T., Khazaeian, A., and Saraeian, A. (2012). "Effect of nanoclay on some applied properties of oriented strand board (OSB) made from underutilized low quality paulownia (Paulownia fortunei) wood," Journal of Wood Science 58, 513524. DOI: $10.1007 / \mathrm{s} 10086-012-1278-2$

Semple, K., Cullis, I., and Evans, P. (2009). Improving the Stability of Oriented Strand Board Manufactured from Mountain Pine Beetle Wood (MPBP Project \#7.37), Wood Surface Science Group, Centre for Advanced Wood Processing, University of British Columbia, Vancouver, Canada.

Silva, A. J. P., Rocco Lahr, F. A., Christoforo, A. L., and Panzera, T. H. (2012). Properties of sugar cane bagasse to use in OSB," International Journal of Materials Engineering 2(4), 50-56. DOI: 10.5923/j.ijme.20120204.04

Sumardi, I., Ono, K., and Suzuki, S. (2007). "Effect of board density and layer structure on the mechanical properties of bamboo oriented strandboard," Wood Science 53, 510-515. DOI: 10.1007/s10086-007-0893-9

Wang, S., Gu, H., and Neimsuwan, T. (2003). "Layer thickness swells and related properties of commercial OSB products: A comparative study," in: $37^{\text {th }}$ Int. Wood Composite Materials Symposium, Washington State Univ., Pullman, WA, pp. 65-76.

Wong, A., Tabarsa, T., Khazaeian, A., and Saraeian, A. (2013). "Improving some of applied properties of oriented strand board (OSB) made from underutilized low quality paulownia (Paulownia fortunie) wood employing nano-SiO 2 ," Industrial Crops and Products 42, 1-9. DOI: 10.1016/j.indcrop.2012.05.010

Wood Based Panels International (2017). "OSB is good for the future," wbpi, (http://www.wbpionline.com/features/osb-is-good-for-the-future-5815765/), Accessed 15 Oct 2019.

Wood Based Panels International (2019). "Developments in the industry - 1995-2018," wbpi, (http://www.wbpionline.com/features/developments-in-the-industry-19952018-6971575/-), Accessed 18 Oct 2019.

Wu, Q., and Piao, C. (1999). "Thickness swelling and its relationship to internal bond strength loss of commercial oriented strandboard," Forest Products J. 49(7/8), 50-55.

Xiao, Y., Li, Z., Wang, R., Shan, B., and Ghavami, K. (2012). "Novel and nonconventional materials and technologies for sustainability," Key Engineering Materials 517, 958. DOI: 10.4028/www.scientific.net/KEM.517

Yong, C., Guan, M. J., and Zhang, Q. S. (2012). "Selected physical and mechanical properties of bamboo and poplar composite OSB with different hybrid ratios," Key Engineering Materials 517, 87-95. DOI: 10.4028/www.scientific.net/KEM.517.87

Yorur, H., Esen, R., and Yapici, F. (2013). "The determination of thickness swelling of oriented strand board (OSB) manufactured from scots pine by using cast-polyamide," ProLigno 9(4), 536-539.

Zhang, Y., Jin, J., and Wang, S. (2007). "Effects of resin and wax on water uptake behavior of wood strands," Wood and Fiber Science 39(2), 271-278.

Article submitted: February 6, 2020; Peer review completed: April 11, 2020; Revised version received and accepted: May 25 2020; Published: June 10, 2020.

DOI: $10.15376 /$ biores. 15.3.5829-5842 